\title{
Agreements Signed by Korea in the XIX Century
}

\author{
Yuliya Yurisovna Karamova ${ }^{1} \&$ Alfiya Rafisovna Alikberova ${ }^{1}$ \\ ${ }^{1}$ Kazan Federal University, Russia \\ Correspondence: Yuliya Yurisovna Karamova, Kazan Federal University, Russia. E-mail: \\ valieva.yul@yandex.ru
}

Received: June 9, 2019

Accepted: August 25, $2019 \quad$ Online Published: August 31, 2019

doi:10.5539/jpl.v12n5p75

URL: https://doi.org/10.5539/jpl.v12n5p75

\begin{abstract}
As a result of the relaxation of the self-isolation policy of the Korean state, the Ganghwa treaty with Japan was signed in 1876. In the same year, the "Rules for trade" and the "Additional articles for the 1876 Treaty" were signed as well, which gave Japanese citizens exterritoriality, opened ports for trade with Japan, allowed them to rent land and more. The American-Korean treaty of peace, friendship, trade and navigation of 1882, the British-Korean (1883), German-Korean (1883), French-Korean (1886) and Russian-Korean (1884) treaties were signed as well, all with similar provisions. When signing agreements with the Korean state, Western countries such as Germany, USA, England etc. applied to China for a letter of recommendation. However, Russia followed a different strategy. Russian diplomat K. I. Veber, authorized to negotiate with the Korean government and sign the Russian-Korean treaty, negotiated directly with King Gojong. South Korean historiographers have different opinions regarding the above treaties signed by Korea with the Western powers.
\end{abstract}

Keywords: history, Russia, Korea, relations, western governments, Japan

\section{Introduction}

The self-isolation policy maintained by the Korean state until 1876, was gradually weakening because of Japan's policy of forced opening of Korean ports. This has led to Korea signing the Ganghwa peace treaty in 1876 (강화도조약, 江華島條約). This was the first unequal treaty signed by Korea and Japan during Japan's policy of forced opening of Korea. This treaty consisted of 12 items. The first article formally declared the "equality of Japan and Korea" However, the treaty was in fact unequal, since it recognized Japanese citizens as not being subject to Korean courts, and permitted Japanese ships to freely enter the waters of Korea to "research" the country's coast. The treaty granted more rights for Japanese merchants in Busan, the traditional place for the Korean-Japanese trade. However, under the treaty, two more ports were to open several years after its signing in places that were new for Japan, in the central and northern parts of the Korean peninsula. These were the Wonsan port on the eastern coast (1879) and Incheon on the western coast (1882). The additional articles to the Ganghwa treaty signed on 24 August established free circulation of Japanese currency in open ports, and the right of Japanese citizens to freely move inland in Korea for a distance up to $10 \mathrm{li}$ from the port. Moreover, the same year saw the signing of the "Rules for trade" and the "Additional articles to the 1876 treaty" that "required Korea to grant exterritoriality and consular jurisdiction to Japanese citizens, open three ports for trade with Japan, allow Japanese to rent land in open ports, and permit Koreans to accept Japanese currency as payment for the goods sold to the Japanese". Why did Korea sign a treaty so unequal? Perhaps the key reason was Japan's demonstration of military force, or perhaps the proponents of the opening up of Korea believed that signing a treaty with Japan would not have negative consequences, since it was an Eastern power that had relations with Korea since ancient times.

However, soon Korea was forced to sign similar treaties with Western states. This partly occurred because of the ever-increasing influence of Japan. The rulers of Qing China worried that China might lose its traditional suzerainty over Korea because of that. To contain Japan, as well as the so-called "northern threat", i.e. the "theoretical aggression" of Russia, the Chinese government suggested Korea to sign treaties with Western states as soon as possible.

At the same time, Western states that maintained active trade links with the neighbouring Japan and China, were also interested in "opening up" Korea. 
As for the policy of Russia regarding the Korean state, it remained the same even after the Japanese-Korean treaty was signed. In other words, Russia continued following the policy of "waiting and seeing". This position can be explained by Russia paying more attention to the events in the Balkans, the upcoming Russian-Turkish war, and by the Russian government being insufficiently informed about the real intentions of the Japanese intervention in Korea. Russia decided to sign the treaty with the Korean state as it saw Western countries trying to open up access to the "country of the morning freshness".

\section{Methods}

The following methods have been used in this paper:

1) analysis of research literature regarding the subject;

2) case study method for analyzing examples;

3) instrumental observation;

Furthermore, this paper uses general scientific methods such as: analysis and synthesis to determine goals, resources and tools of the subject concept, as well as structural approach.

\section{Results and Discussion}

The first Western country that signed a treaty with Korea to establish relations was the United States. As early as 1878, the American government sent Commander R. V. Shuffeld as its plenipotentiary representative, with an assignment to work on establishing the relations between the two countries. In 1880, after arriving to Busan, he tried to pass to King Gojong an offer for a treaty via the Japanese, but his attempt was futile. Only the insistence of China, represented by the commander of the Northern Fleet Li Hongzhang, forced the Korean government to get to the negotiating table in Incheon, and on 22 May 1882, the Korean-American treaty of peace, friendship, trade and navigation (조·미수호통상조약, 朝美修好通商條) was signed. It consisted of 14 articles. Similarly to the agreement with Japan, the Korean-American treaty was also unequal for Korea and denied Korean courts jurisdiction over American citizens in Korea. This American-Korean treaty granted Americans the rights of exterritoriality, consular jurisdiction, and permitted Americans to build houses and warehouses in open ports of Korea, as well as to conduct trade. Furthermore, under this treaty the Korean state was to assist any American vessels that crashed near the shores of Korea. Notably, the 1882 American-Korean treaty makes no mention of the vassal dependency of Korean from China, which should have made it easier for the US to further penetrate the Korean state. Since the vassal dependency of the Korean state was not mentioned in treaties signed with England, Germany, Russia and other Western states, China required "the Korean king to send the ruler of the relevant country a letter formally recognizing the supreme authority of the Chinese emperor". The British-Korean (1883), German-Korean (1883), French-Korean (1886) and Russian-Korean (1884) treaties were all signed with similar content.

When signing agreements with the Korean state, Western countries such as Germany, USA, England etc. applied to China for a letter of recommendation. However, Russia followed a different strategy. Russian diplomat K. I. Veber (1841-1910), authorized to negotiate with the Korean government and to sign the Russian-Korean treaty, negotiated with the King Gojong directly. K. I. Veber was forced to choose this path because of China. "Chinese authorities, fearing for losing their traditional influence in Korea due to the increasingly strong positions of Japan in the Korean peninsula, have recommended to the Korean court to sign treaties with Western states, hoping thus to contain Japan." Chinese General Li Hongzhang (李鸿章, 1823-1901) was against Korea's signing of a treaty with Russia. He feared that: first, the treaty may reinforce Russian influence in Korea, and second, as a result of the treaty Russia may annex some Korean land. Foreseeing China's refusal to grant a letter of recommendation for the treaty between Korea and Russia, K. I. Veber decided to contact the Korean government directly. In this way, 1884 saw the signing of the Russian-Korean Treaty of Peace and Trade (한로수호통상조약, 朝露修好通商條約). On the occasion of its signing, the Korean king sent a letter to the Russian Emperor that said that "Korea up until now is a country that is subject to China's rule, but since the ancient times, the Korean king has autonomy over foreign relations. Under this treaty, which is currently in force between Korea and Russia, both governments are fully equal in their relations, and the King of Korea positively affirms that all articles of the treaty will be performed fairly and truthfully, in accordance with his sovereign power and international law. As for the fact that Korea is a country that is subject to China's rule, any obligations arising from that are in no way related to Russia".

The Russian-Korean agreement contained 13 articles. This treaty established diplomatic relations between the Russian Empire and the Korean state. The Russian diplomatic mission in Seoul opened in 1885-1886. The first envoy in 1886-1897 was K. I. Veber. The treaty also granted exterritoriality and consular jurisdiction. Russians were granted the right to trade, rent, or buy land and buildings, build houses, enterprises and warehouses in open 
ports of Korea, and Russian navy and Korean ships could visit each other's ports for repairs or restocking. An appendix to the treaty was titled "Rules for trade by Russian citizens in Korea", which contained three articles and a list of customs tariffs for 196 types of goods. The Russian-Korean treaty was ratified on 14 October 1885 . As a result of the active development of trans-border trade, the Russian-Korean treaty was supplemented with the "Rules for land-based trade with Korea", signed in 1888. This convention consisted of 9 articles and significantly expanded the rights of the Russian Empire in the area bordering Korea.

\section{Summary}

In 1876, Korea signed the Ganghwa Peace Treaty (강화도조약, 江華島條約). This was the first unequal treaty signed by Korea and Japan during Japan's policy of forced opening of Korea. In 1882, the American-Korean treaty of peace, friendship, trade and navigation (조·미수호통상조약, 朝美修好通商條) was signed. Similarly to the Japanese-Korean treaty, this American-Korean treaty granted Americans exterritoriality, consular jurisdiction, as well as permitted Americans to build houses and warehouses in open ports of Korea, and to conduct trade. The British-Korean (1883), German-Korean (1883), French-Korean (1886) and Russian-Korean (1884) treaties were all signed with similar content.

\section{Conclusions}

South Korean historiographers have different opinions regarding the above treaties signed by Korea with the Western powers. Some of them are united in the opinion that "all signed treaties granted exterritoriality, consular jurisdiction, the right to conduct trade and build houses and warehouses, which in fact was an attack on the Korean sovereignty. Many treaties were signed with China acting as an intermediary, thereby hoping to keep the "country of morning freshness" as its vassal, and to arrest the attempts of Japan to expand its influence in Korea", while there are also researchers who see some benefits of those treaties for Korea, despite being unequal. Let us quote a joint study of South Korean researchers and researchers from Harvard: "The treaties signed by the Korean state with Western countries, although being unequal, still contained three benefits for Korea". These benefits were: first, assistance promised to Korea against the threat from other states; second, high-percentage tariffs that benefited the early Korean industry, and third, the parties signing treaties with Korea promised to formally renounce exterritoriality if the Korean state executes reforms and the Korean authorities and courts will be transformed in the Western manner. At the same time, Korea started its modernization, which was connected with active borrowing of the achievements of the world civilization.

\section{Acknowledgements}

The work is performed according to the Russian Government Program of Competitive Growth of Kazan Federal University.

\section{References}

Beloglasov, A. (2015). Russia's policy on providing security in central Asia at the beginning of the XXI century. Mediterranean Journal of Social Sciences, 6(3), 219-226. https://doi.org/10.5901/mjss.2015.v6n3s2p219

Eckert, J. (1990). Korea old and new. A history.

$\begin{array}{lllll}\text { Encyclopedia } & \text { of } & \text { Korean } & \text { Culture. } & \text { Retrieved }\end{array}$ http://encykorea.aks.ac.kr/Contents/Index?contents_id=E0052349

Han, W.-K. (1970). The History of Korea.

Kim, C. (1967). Eugene Korea and the Politics of Imperialism (1876-1910).

Kim, C. H. (2001). Russian-Korean diplomatic relations in 1884-1904.

Kowner, R. (2000). Historical Dictionary of the Russo-Japanese War.

Kurbanov, S. (n.d.). Russia and Korea. Key moments in the history of Russian-Korean relations in mid-XIX early XX centuries. Koryo saram: notes about Koreans. Retrieved from https://koryo-saram.ru/kurbanov-s-o-rossiya-i-koreya-klyuchevy-e-momenty-v-istorii-rossijsko-korejskih-ot noshenij-serediny-xix-nachala-xx-stoletij/

Li, H. Z. (n.d.). ABIRUS: Asian Business Information for Russians. Retrieved from http://www.abirus.ru/content/564/623/626/12557/12584.html

National Institute of Korean History. Retrieved from $\mathrm{http}: / /$ contents.history.go.kr/front/tg/view.do?treeId=0200\&levelId=tg_004_0970\&ganada=\&pageUnit=10.

Pak, B. (2004). Russia and Korea, p. 540. 
Penkovtsev, R., \& Shibanova, N. (2015). Wars and military conflicts of the XXI century in the context of the strategic interests of the United States. Journal of Sustainable Development, 8(4), 164-168. https://doi.org/10.5539/jsd.v8n4p164

Seoul Treaty of 1884, Great Russian Encyclopedia. Retrieved from https://bigenc.ru/domestic_history/text/3659670

Yeoh, E. (2018). Brave new world meets nineteen eighty-four in a new golden age: On the passing of Liu Xiaobo, advent of big data, and resurgence of China as world power. Contemporary Chinese Political Economy and Strategic Relations, 4(2), 593-764.

Zabrovskaya, L. (1987). Policy of Qing Empire in Korea. 1876-1970. p. 300.

Zinoviev, V. (2013). Modern historiography of industrial personnel of pre-revolutionary Siberia. Siberian Historical Research, (1), 31-41.

\section{Copyrights}

Copyright for this article is retained by the author(s), with first publication rights granted to the journal.

This is an open-access article distributed under the terms and conditions of the Creative Commons Attribution license (http://creativecommons.org/licenses/by/4.0/). 